\title{
УДОСКОНАЛЕННЯ СТОМАТОЛОГІЧНОЇ ДОПОМОГИ ВІЙСЬКОВОСЛУЖБОВЦЯМ ЗБРОЙНИХ СИЛ УКРАЇНИ У ВІДПОВІДНОСТІ ДО ВИМОГ СТАНДАРТІВ НАТО
}

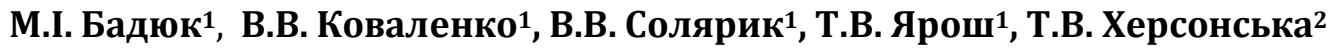

\author{
1Українська військово-медична академія, м. Київ, Україна \\ ${ }^{2}$ Центральна стоматологічна поліклініка Міністерства оборони України, м. Київ, Україна
}

\begin{abstract}
Мета. Наукове обгрунтування шляхів удосконалення стоматологічної допомоги військовослужбовцям ЗС України через досягнення сумісності медико-технологічних документів надання стоматологічної допомоги із стандартами НАТО.

Методи дослідження. Методологія дослідження базувалася на системному підході. Для вирішення поставлених завдань застосовувались наступні методи досліджень: системного аналізу (системноісторичний; системно-структурний; системно-елементний; системно-комунікативний) $i$ методи статистичного аналізу.

Результати. Уході дослідження проаналізовані показники роботи стоматологічної служби ЗС України під час виконання миротворчих місій (Ліберія, Конго) та в умовах ведення АТО/ОоС. Досліджені стандарти НАТО з організації стоматологічної допомоги в умовах ведення збройного конфлікту та визначені можливі напрямки удосконалення стоматологічної допомоги військовослужбовцям ЗС Украӥни шляхом адаптування вітчизняних стандартів до стандартів НАТО. Матеріали дослідження знайшли своє відображення у розробленому колективом стоматологічної служби ЗС України "Збірнику локальних клінічних протоколів надання стоматологічної допомоги військовослужбовцям з основними хворобами органів порожнини рота в зоні проведення бойових дій” (2017р.), які на сьогодні використовуються лікарями-стоматологами ЗС Украӥни в практичній діяльності.

Висновки. Проведене дослідження дозволяє стверджувати, що наявна організаційно-штатна структура стоматологічної служби ЗС України дозволяє в повному обсязі застосувати стандарти НАТО та адаптувати алгоритми і протоколи надання медичної допомоги військовослужбовцям ЗС України при пораненнях в ЩЛД в умовах ведення збройного конфлікту.

Ключові слова: локальні клінічні протоколи, стандарти НАТО, сумісність медико-технологічних документів, станаги, хвороби органів порожнини рота, удосконалення стоматологічної допомоги.
\end{abstract}

Вступ. Комплектування бойових підрозділів Збройних Сил (ЗС) України під час часткової мобілізації, в умовах ведення антитерористичної операції - операції Об'єднаних сил (АТО/ООС), відбувається на тлі високої стоматологічної захворюваності населення держави $[6,11]$. В той же час, особливості патогенезу сучасних бойових уражень і захворювань, їх тяжкість, наявність і вплив коморбідності, обумовлюють складні та різноманітні ускладнення, що в свою чергу може впливати на перебіг бойової травми щелепно-лицевої ділянки (ЩЛД) і на прогноз для пораненого [7].

Збройний конфлікт на сході України значно прискорив усвідомлення необхідності удосконалення системи медичного забезпечення військ [5]. Разом 3 тим, адаптування нормативно-правових актів України у сфері національної безпеки до євроатлантичних норм та стандартів сьогодні висуває нові вимоги до медичного забезпечення ЗС України [1].
Отже, удосконалення стоматологічної допомоги військовослужбовцям 3С України у відповідності до стандартів НАТО обумовило актуальність даного дослідження і визначило його мету.

Мета дослідження - наукове обгрунтування шляхів удосконалення стоматологічної допомоги військовослужбовцям 3С України через досягнення сумісності медико-технологічних документів надання стоматологічної допомоги із стандартами НАТО.

Матеріали та методи дослідження. В ході роботи проводилося дослідження показників роботи стоматологічної служби $3 \mathrm{C}$ України під час виконання миротворчих місій та в умовах ведення збройного конфлікту, а також визначалися можливі напрямки удосконалення надання стоматологічної допомоги військовослужбовцям 3С України шляхом адаптування вітчизняних стандартів до стандартів НАТО. Методологія дослідження базувалася на системному підході. Для 
вирішення поставлених завдань застосовувались наступні методи досліджень: системного аналізу (системно-історичний; системно-структурний; системно-елементний; системно-комунікативний) і методи статистичного аналізу (критерії $\chi^{2}$ - Пірсона і t - Стьюдента) [2, 3].

Результати дослідження та їх обговорення. На першому етапі дослідження проаналізований досвід стоматологічного забезпечення українських миротворчих батальйонів. Вивчені показники та обсяг надання стоматологічної допомоги військовослужбовцям миротворчих підрозділів 3С України у Ліберії (56 окремий вертолітний загін) та Конго (18 окремий вертолітний загін) у 2016 році (табл. 1).

Таблиця 1

Види та обсяги стоматологічної допомоги, наданої досліджуваним контингентам у 2016 р.

\begin{tabular}{|c|c|c|c|c|c|c|}
\hline \multirow{2}{*}{ Контингент } & \multicolumn{5}{|c|}{ Вид допомоги } & \multirow{2}{*}{ всього } \\
\hline & карієс & пульпіт & періодонтит & пародонтит & хірург & \\
\hline 56-й ОВЗ (Ліберія) & 181 & 86 & 94 & 16 & 27 & 374 \\
\hline 18-й ОВЗ (Конго) & 156 & 34 & 71 & 22 & 14 & 297 \\
\hline $\begin{array}{c}\text { Миротворчий } \\
\text { контингент в цілому }\end{array}$ & 337 & 120 & 165 & 38 & 41 & 701 \\
\hline $\begin{array}{l}\text { 95-а ОДШБр } \\
\text { (АТО/ООС) }\end{array}$ & 1578 & 822 & 2108 & 182 & 1382 & 6072 \\
\hline
\end{tabular}

Встановлено, що лікарі-стоматологи вели, в основному, амбулаторний прийом миротворців 3 різноманітними хворобами органів порожнини рота (ХОПР). 3 аналізу отриманих результатів виходить, що не дивлячись на різницю у структурі допомоги в цілому $\quad\left(p_{\alpha}\left(\chi^{2}, \quad d f=4\right)=0,00003\right), \quad$ в обох контингентах переважає захворюваність на карієс порівняно із рештою патології порожнини рота військовослужбовців, що склало відповідно $(44,8 \pm 4,9) \%$ у Ліберії та $(52,5 \pm 5,7) \%$ у Конго (рис.1А, рис.1Б).

Аналіз структури надання стоматологічної допомоги всієї миротворчої місії у 2016 р. (табл.1) показує аналогічну ситуацію i засвідчує статистично значуще переважання надання терапевтичної стоматологічної допомоги над хірургічною: $(98,4 \pm 1,0) \%$ проти $(6,1 \pm 1,0) \%\left(p_{\alpha}(t, d f)<0,05\right), 3$ явним переважанням карієсу, $(48,1 \pm 3,7) \%$, над його ускладненими формами: пульпітами та періодонтитами та парадонтозами $\left(p_{\alpha}(t\right.$, $d f)<0,05)$, (рис. 1B). На другому етапі дослідження нами проаналізований досвід стоматологічного забезпечення 95-ої ОДШБр, розгорнутої в зоні проведення АТО/ООС на території Донецької області (табл.1). Звертає на себе увагу та обставина, що в структурі надання стоматологічної допомоги у 95-й ОДШБр у зоні проведення АТО/ООС, у 2016 р. терапевтична патологія в цілому зустрічалася достовірно частіше $\left(p_{\alpha}(t, d f)<0,05\right)$ ніж хірургічна (рис. $1 \Gamma)$ : $(77,2 \pm 1,1) \%$ та $(22,8 \pm 1,1) \%$ відповідно. В свою чергу, серед терапевтичної допомоги $є$ переважання ускладнених форм: періодонтиту та пульпіту, над простим карієсом (рис. $1 \Gamma)$, що складає $(48,3 \pm 1,3) \%$ та $(26,0 \pm 1,1) \%$ відповідно. Зважаючи на це, нами проведений порівняльний аналіз надання стоматологічної допомоги у миротворчій місії (Ліберія, Конго) та 95-й ОДШБр у зоні проведення АТО/ООС у 2016 р. (табл. 1) який засвідчив, що структура надання медичної допомоги у 95-й ОДШБр відрізняється від аналогічної структури миротворчого контингенту в цілому $\left(p_{\alpha}\left(\chi^{2}, d f=4\right)=0,000001\right)$. При порівнянні за окремими видами патології відзначається достовірне збільшення $\left(p_{\alpha}(t)\right.$ $d f)<0,05)$ частки хірургічної стоматологічної допомоги у зоні проведення АТО/ООС порівняно із миротворчим контингентом: $(22,8 \pm 1,1) \%$ проти $(5,8 \pm 1,1) \%$, i, відповідно, достовірне збільшення $\left(p_{\alpha}(t, d f)<0,05\right)$ частки терапевтичної стоматологічної допомоги під час виконання миротворчої місії: $(94,2 \pm, 1) \%$ проти $(77,2 \pm 1,1) \%$.

Результати наших досліджень дозволяють стверджувати, що у більшості військовослужбовців при виконанні миротворчих місій та в зоні проведення AT0/OOC діагностувалися та лікувалися переважно гострі форми стоматологічних захворювань: гострий глибокий карієс та його ускладнені форми (пульпіт, періодонтит), 
захворювання парадонту та ін., що може свідчити про низький рівень санації та неналежне проведення військово-лікарської експертизи при формуванні контингенту для
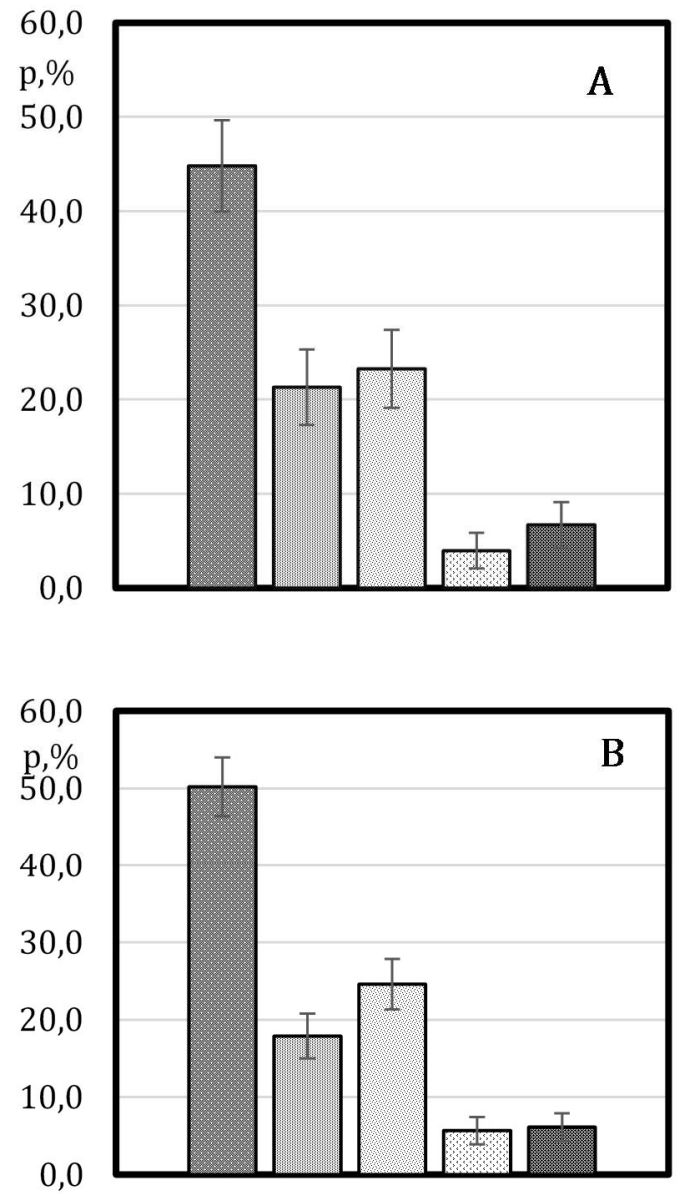

๑карієс $\square$ пульпіт $\square$ періодонтит миротворчих місій та перед відбуттям в зону ATO/OOC.
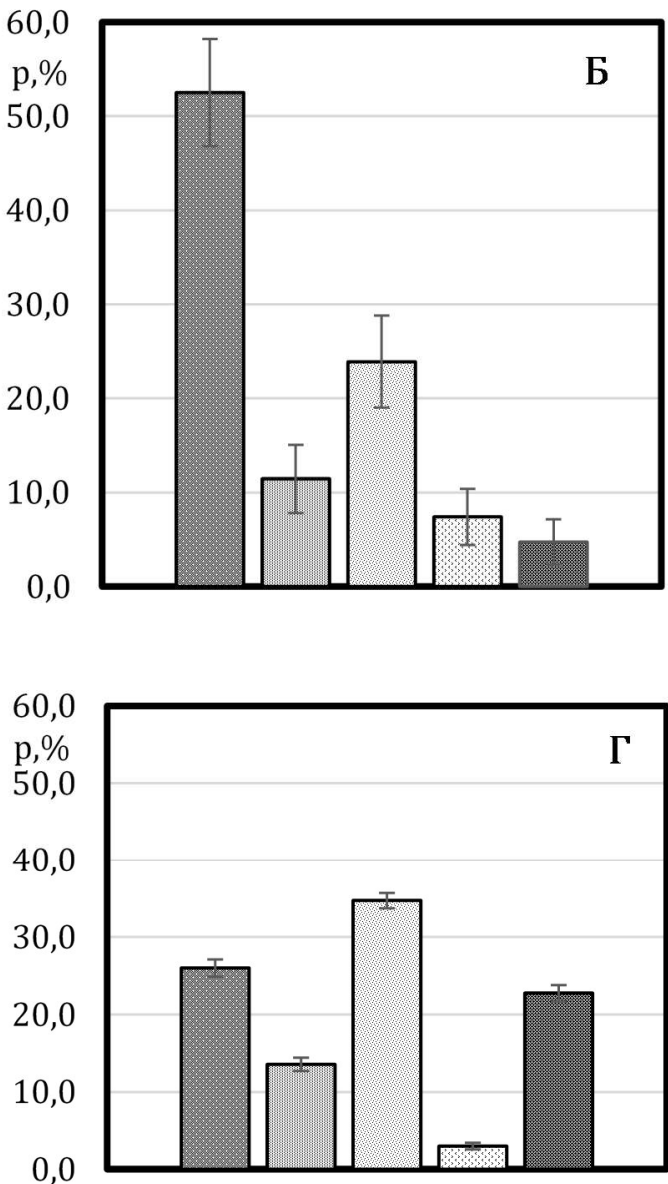

0,0

A- y 56-му окремому вертолітному загоні в Ліберії, Б - у 18-у окремому вертолітному загоні в Конго, В - у всій миротворчій місії, $Г$ - у 95 ОДШБр у зоні проведення АТО/OOC.

Рисунок 1. Структура надання стоматологічної допомоги у 2016 р, \%

В той же час, заходи захисту здоров'я військовослужбовців країн-членів НАТО $\epsilon$ невід'ємним елементом в системі боєготовності військ. Документ AJP-3.14 "Спільна доктрина захисту сил" визначає охорону здоров'я як дуже важливу складову їх захисту [13]. Національні військові командування та командування НАТО наголошують на важливості забезпечення належного рівня медичного, стоматологічного і психічного здоров'я військ. Досвід країн альянсу стверджує, що наявність стоматологічних захворювань зменшує бойову готовність військ. Планові стоматологічні обстеження та стандартизовані програми лікування гарантують, що особовий склад буде залишатися здоровим під час розгортання військ при виконанні миротворчих місій та в зоні ведення воєнних дій [13].

Відповідно до стандарту STANAG 2466 "Стандарти стоматологічного здоров'я військовослужбовців і система класифікації стоматологічного здоров'я" (Dental Fitness Standards for Military Personnel and a Dental Fitness Classification System), що регламентує контроль за станом стоматологічного здоров'я військовослужбовців ще до розгортання медичних підрозділів в зоні ведення бойових дій, в НАТО впроваджена система комплексної профілактики стоматологічної захворюваності серед військовослужбовців [14]. Система планових стоматологічних обстежень, профілактичних заходів та єдиних 
стандартизованих програм лікування мінімізує потрапляння військовослужбовців 3 гострими формами ХОПР в зону ведення бойових дій. Тому, удосконалюючи стоматологічну допомогу військовослужбовцям $3 \mathrm{C}$ України, слід врахувати цю обставину і привести її у відповідність до вимог стандартів НАТО, де здоровими 3 точки зору стоматології ("DENTALLY FIT") є військовослужбовці армій країн HATO, які відносяться до DENTAL FITNESS CLASS 1 (військовослужбовці, які не потребують стоматологічного лікування) та DENTAL FITNESS CLASS 2 (військовослужбовці, існуючий стан стоматологічного статусу 3 великою ймовірністю не приведе до розвитку гострих ХОПР протягом 12 місяців) [14].

Достовірне збільшення $\left(p_{\alpha}(t, d f)<0,05\right)$ частки хірургічної стоматологічної допомоги у зоні проведення АТО/ООС порівняно із миротворчим контингентом: $(22,8 \pm 1,1) \%$ проти $(5,8 \pm 1,1) \%$, i, відповідно, достовірне збільшення $\quad\left(p_{\alpha}(t, \quad d f)<0,05\right) \quad$ частки терапевтичної стоматологічної допомоги під час виконання миротворчої місії: $(94,2 \pm, 1) \%$ проти $(77,2 \pm 1,1) \%$ може свідчити про збільшення поранень та щелепно-лицьових травм 3 пошкодженням кісток лицевого скелету, питома вага яких серед поранених в зоні проведення АТО/ООС, за даними літератури, становить $2 \%[9,10]$.

Третій етап нашого дослідження присвячений вивченню досвіду стоматологічного забезпечення провідних країн НАТО, який знайшов своє відображення в STANAG 2453 AMedP-35 «Обсяг стоматологічного та щелепно-лицевого лікування на ролях 1-3» (The Extent of Dental And Maxillo-facial Treatment at Role 1-3) [15]. Цей стандарт висвітлює кадрове і матеріально-технічне забезпечення, порядок та обсяг стоматологічної допомоги в зоні ведення бойових дій і передбачає наявність 5 категорій фахівців стоматологічного профілю (рис. 2).

В системі стоматологічного забезпечення 3С України передбачені всі перелічені фахівці, але, разом з тим, в Україні юридично не існує щелепно-лицевих хірургів, хоча при цьому хірурги-стоматологи мають право надавати повний обсяг хірургічної допомоги пораненим у ЩЛД та хворим 3 ХОПР. Рівню стоматологічного офіцера (DO) та орального хірурга (OS) відповідає лікар-стоматолог 3С України. В структурі стоматологічної служби 3С України передбачені також посади медичної сестри стоматологічної та операційної медичної сестри, які відповідають професійному рівню асистента стоматолога (DA) та асистенту щелепно-лицевого хірурга (SA).

\begin{tabular}{|l|c|l|l|}
\hline № & \multicolumn{1}{|c|}{ Назва фаху } & Kод & \multicolumn{1}{|c|}{ Вимоги } \\
\hline 1. & $\begin{array}{l}\text { Стоматологічний } \\
\text { офіцер } \\
\text { (лікар-стоматолог })\end{array}$ & DO & $\begin{array}{l}\text { Особа, яка має національну ліцензію та } \\
\text { освіту для надання стоматологічної } \\
\text { допомоги та/або оральної хірургії }\end{array}$ \\
\hline 2. & $\begin{array}{l}\text { Оральний хірург } \\
\text { (хірург-стоматолог) }\end{array}$ & OS & $\begin{array}{l}\text { Особа, яка має національну ліцензію та } \\
\text { освіту для надання допомоги а галузі } \\
\text { оральної хірургії }\end{array}$ \\
\hline 3. & $\begin{array}{l}\text { Щелепно-лицевий } \\
\text { хірург }\end{array}$ & OMFS & $\begin{array}{l}\text { Особа, яка має національну ліцензію та } \\
\text { освіту для надання допомоги а галузі } \\
\text { щелепно-лицевої хірургії }\end{array}$ \\
\hline 4. & $\begin{array}{l}\text { Асистент } \\
\text { стоматолога }\end{array}$ & DA & $\begin{array}{l}\text { Особа, яка має національну ліцензію та } \\
\text { освту та має право асистувати } \\
\text { стоматологу }\end{array}$ \\
\hline 5. & $\begin{array}{l}\text { Асистент щелепно- } \\
\text { лицевого хірурга }\end{array}$ & SA & $\begin{array}{l}\text { Особа, яка відповідно до національної } \\
\text { ліцензії та освіти, має право асистувати } \\
\text { щелепно-лицевому хірургу }\end{array}$ \\
\hline
\end{tabular}

Рисунок 2. Перелік фахівців стоматологічного профілю в зоні ведення бойових дій в країнах НАТО.

Фахівці стоматологічного профілю в зоні ведення бойових дій арміями країн НАТО розподіляються на різних рівнях надання медичної допомоги (рис. 3).

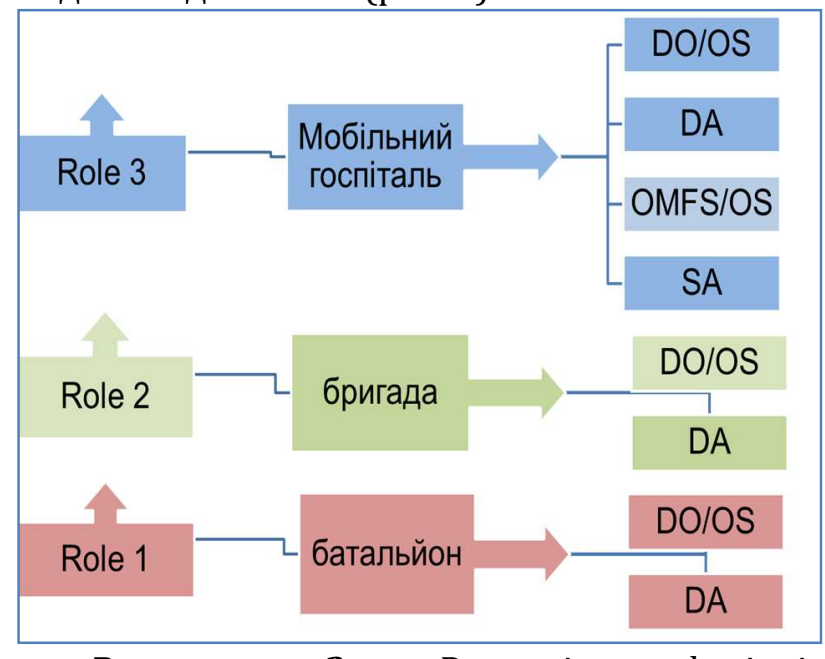

Рисунок 3. Розподіл фахівців стоматологічного профілю в зоні ведення бойових дій країнами НАТО.

Важливим елементом в забезпеченні медичної допомоги в зоні проведення ATO/OOC на Сході України є чітке визначення обсягу стоматологічної допомоги на різних рівнях їі надання. Основною складовою STANAG 2453 AMedP-35 "Обсяг стоматологічного та щелепно-лицевого лікування на ролях 1-3" є саме обсяг медичної допомоги в зоні ведення бойових дій силами євроатлантичного альянсу [15]. Цей обсяг чітко визначений та структурований $\mathrm{y}$ 
відповідності до рівня надання допомоги (табл. 2).

Відповідно до STANAG 2453 AMedP-35, лікар-стоматолог та асистент стоматолога в країнах НАТО присутній вже на рівні батальйону (Role1), але в деяких країнах Альянсу (Іспанія, Хорватія, Словаччина) ці фахівці на цьому рівні надання медичної допомоги в зоні ведення бойових дій відсутні [15].

Україна має достатній досвід участі своїх миротворчих сил в різноманітних місіях під егідою ООН. У складі медичних підрозділів усіх миротворчих батальйонів присутній також i лікар-стоматолог. Разом з тим, забезпечити лікарем-стоматологом кожен батальйон, що приймає участь у веденні бойових дій на сучасному етапі розбудови та розвитку 3С України, відповідно до існуючої організаційноштатної структури стоматологічної служби 3С України, немає потреби, оскільки на цьому етапі в разі необхідності можна використовувати мобільні стоматологічні підрозділи - пересувні стоматологічні кабінети (ПСК) медичних рот (медр) бригад та ПСК МВГ.

Таблиця 2

Обсяг стоматологічної допомоги в арміях країн НАТО

\begin{tabular}{|c|c|c|c|}
\hline Рівень & Де надається & Вид допомоги & Хто надає \\
\hline Role 1 & батальйон & невідкладна стоматологічна & DO/OS, DA \\
\hline \multirow{3}{*}{ Role 2 } & бригада & первинна стоматологічна & DO/OS, DA \\
\cline { 3 - 4 } & мобільний & оральна хірургія & DO/OS, DA/SA \\
\cline { 3 - 4 } Role 3 & госпіталь & вторинна стоматологічна & DO, DA \\
\cline { 3 - 4 } & & щелепно-лицева хірургія & OMFS/OS, SA \\
\hline
\end{tabular}

Наступний рівень стоматологічної допомоги (Role2) в країнах НATO представлений стоматологічним офіцером або оральним хірургом та асистентом в бригаді. В 3C України в штаті медичної роти механізованої (мотопіхотної, танкової) бригади передбачений ПСК: призначений для надання медичної допомоги пораненим в ЩЛД. До складу кабінету входять: начальник кабінету (лікар-стоматолог); медична сестра і водій-електрик.

Обсяг стоматологічної допомоги, що надається лікарем-стоматологом ПСК бригади, відповідає обсягу НATO (Role2) та включає базову (первинну) терапевтичну стоматологічну i амбулаторну хірургічну стоматологічну допомогу. Цей обсяг, майже повністю, співпадає 3 первинною стоматологічною допомогою (Primary dental care) i стоматологічною альвеолярною хірургією (Dental alveolar surgery), відповідно до STANAG 2453 AMedP-35 [15].

Наступний, третій (Role 3), рівень надання стоматологічної допомоги в зоні проведення бойових дій в НАТО представлений мобільним госпіталем, де присутні як стоматологи (DO/OS), так і щелепно-лицеві хірурги (OMFS) з відповідними асистентами.

В районі проведення АTO/OOC на території Донецької та Луганської областей розгорнуто чотири військові мобільні госпіталі - 59, 65, 66 і 61, які за призначенням відповідають, в основному, мобільним госпіталям країн НАТО, а обсяг медичної допомоги військовослужбовцям 3 ушкодженнями ЩЛД та ХОПР відповідає описаному в STANAG 2453 AMedP-35 рівню 3 (Role3), тобто обсягу «вторинної стоматологічної допомоги»[15].

Організаційно-штатна

структура стоматологічної служби ВМГ, в цілому, відповідає стандартам НАТО, а наявний в штаті ВМГ ПСК дає змогу наблизити допомогу пораненим в ЩЛД до рівня батальйон-бригада [8]. Відповідно до завдань, начальник ПСК окрім основної спеціалізації "Стоматологія" повинен мати додаткову спеціалізацію 3 "Хірургічної стоматології", а ординатор цього мобіль-ного стоматологічного підрозділу фахівець, який має спеціалізацію «Стоматологія».

Начальник стоматологічного кабінету ВМГ, маючи спеціалізацію 3 "Хірургічної стоматології", в змозі надавати вторинну (спеціалізовану) медичну допомогу (Role 2) військовослужбовцям 3 ушкодженнями (бойовими та небойовими) та захворюваннями ЩЛД.

Ординатор стоматологічного кабінету ВМГ - фахівець, який має спеціалізацію зі «Стоматології» здатний забезпечити змішаний амбулаторний терапевтичний та хірургічний стоматологічний прийом поранених і хворих з ХОПР $[9,10]$.

Після отримання належної допомоги поранені та хворі евакуюються до профільних клінік ЩЛХіСт ВМКЦ Північного регіону (м. Харків) та ОКЛ ім. Мечникова або ВГ 
(м. Дніпро) [10, 12].

Розподіл сил стоматологічної служби в загальній схемі лікувально-евакуаційних заходів в умовах збройного конфлікту (період стабільної та контрольованої ситуації) можна представити наступним чином: Role 1 первинна (екстрена) медична допомога начальник ПСК медр омбр та начальник ПСК ВМГ; Role 2 - спеціалізована медична допомога - начальник стоматологічного кабінету ВМГ; Role 3,4 - третинна (високоспеціалізована) медична допомога - щелепно-лицьові хірурги і стоматологи профільних клінік ЩЛХіСт ВМКЦ Північного регіону (м. Харків) або ОКЛ ім. Мечникова та ВГ (м. Дніпро).

\section{Висновки}

1. Науковий аналіз світових і вітчизняних джерел інформації щодо поглядів на організацію надання стоматологічної допомоги військовослужбовцям за стандартами НАТО в умовах ведення збройних конфліктів підтвердив їх дієвість і ефективність та дозволив обгрунтувати потребу в удосконаленні стоматологічної допомоги військовослужбовцям ЗС України у відповідності до вимог стандартів НАТО.

2. Порівняльний аналіз надання стоматологічної допомоги у батальйонах миротворчих місій (Ліберія, Конго) та у 95-й ОДШБр в умовах ведення збройного конфлікту, засвідчив достовірне збільшення $\left(p_{\alpha}(t, \quad d f)<0,05\right) \quad$ частки хірургічної стоматологічної допомоги у зоні збройного конфлікту, i, відповідно, достовірне збільшення $\quad\left(p_{\alpha}(t, \quad d f)<0,05\right) \quad$ частки терапевтичної стоматологічної допомоги під час виконання миротворчих місій, що акцентує увагу на потребі у підсиленні хірургічної компоненти стоматологічної допомоги в умовах ведення збройного конфлікту.

3. Порівняльний аналіз українського законодавства в сфері надання стоматологічної допомоги в ЗС України зі стандартами НАТО засвідчив можливість досягнення

\section{Література}

1. Бадюк М.I. Аналіз роботи медичної служби щодо пріоритетних напрямків розробки та впровадження стандартів медичного забезпечення Збройних Сил України на особливий період / M.I. Бадюк, О.О. Микита, А.В. Швець, І.К. Середа, Д.В. Ковида, А.М. Губар. // Проблеми військової охорони здоров’я: зб. наук. пр. - К.: УВМА, 2016. - № 45. - С. 9-16.
Обсяг рівнів стоматологічної допомоги, 3 урахуванням вимог стандартів НАТО, знайшов своє відображення в розробленому колективом стоматологічної служби $3 \mathrm{C}$ України «Збірнику локальних клінічних протоколів надання стоматологічної допомоги військовослужбовцям з основними хворобами органів порожнини рота в зоні проведення бойових дій» (2017 р.), де відображені шифр МКХ, критерії діагностики, обсяг різних рівнів надання невідкладної стоматологічної допомоги, результати лікування та критерії ефективності, що використовується лікарями-стоматологами 3С України в практичній діяльності [4].

сумісності нормативно-правових та медикотехнологічних документів i визначив доцільність розробки та впровадження актуальних адаптованих алгоритмів i протоколів надання екстреної медичної допомоги військовослужбовцям у невідкладних станах при пораненнях у ЩЛД.

4. Проведене дослідження дозволяє стверджувати, що наявна організаційноштатна структура стоматологічної служби ЗС України (наявність ПРК в штатах бригад і ВМГ, а також стоматологічних кабінетів у ВМГ) дозволяє в повному обсязі застосувати стандарти НАТО та адаптувати алгоритми і протоколи надання медичної допомоги військовослужбовцям $3 \mathrm{C}$ України при пораненнях в ЩЛД в умовах ведення збройного конфлікту.

5. Матеріали дослідження знайшли своє відображення у розробленому колективом стоматологічної служби ЗС України “Збірнику локальних клінічних протоколів надання стоматологічної допомоги військовослужбовцям 3 основними хворобами органів порожнини рота в зоні проведення бойових дій” (2017 р.) та використовуються лікарямистоматологами $3 \mathrm{C}$ України в практичній діяльності.

2. Бадюк M.I. Основні шляхи досліджень у військовій медицині: Навч. посібник / Бадюк M.I., Ярош Т.В. -К.: УВМА, 2011. -292 с.

3. Бадюк М.I., Ярош Т.В. Методичні рекомендації до виконання індивідуальних завдань / Бадюк M.I., Ярош Т.В. та ін. -К.: “Видавництво Людмила”, 2019. $-92 \mathrm{c}$. 
4. Збірник локальних клінічних протоколів надання стоматологічної допомоги військовослужбовцям 3 основними хворобами органів порожнини рота в зоні проведення бойових дій / Коваленко В.В., Лихота А.М., М.З. Лищишин та ін. К.: 2017. -45 с.

5. Екстрена медична допомога військовослужбовцям на догоспітальному етапі в умовах збройних конфліктів : Навч. посіб. / М. І. Бадюк [та ін.]. За ред. проф. М. І. Бадюка; - Київ : СПД Чалчинська Н. В., 2018. - 204 с.

6. Клименко В. І., Смірнова I.В. Чинники ризику виникнення стоматологічних захворювань у населення працездатного віку // Запорізький мед. журнал. -2014. - №4 (85). -С. 60-62.

7. Коваленко. В.В. Євроатлантичні перспективи вітчизняної стоматології [Текст] - Euro-Atlantic Prospects of World Dentistry / В. В. Коваленко, М. 3. Лищишин // Новини стоматології : наук.-практ. журн. - 2017. - № 2. - С. 24-27.

8. Коваленко В. В. Особливості організації стоматологічної допомоги в зоні проведення антитерористичної операції на Сході України / В. В. Коваленко, М. 3. Лищишин // Новини стоматології. - 2016. - №4. - С. 101.

9. Коваленко В.В. Організація та обсяг стоматологічної допомоги військовослужбовцям в зоні проведення бойових дій (на досвіді

\section{References}

1. Badiuk, M.I. Mykyta, O.O., Shvets, A.V., Sereda, I.K., Kovyda, D.V. Hubar, A.M. (2016). Analysis of the work of the medical service on the priority areas of development and implementation of standards of medical support of the Armed Forces of Ukraine for a special period. Military Health Problems: Coll. Sci. Paper. UMMA. (45). 9-16.

2. Badiuk, M.I., Yarosh, T.V. (2011). The main ways of research in military medicine: Textbook. Manual. UVMA. 292 p.

3. Badiuk, M.I., Yarosh, T.V. etc. (2019). Methodical recommendations for individual tasks. $\mathrm{K}$ :: Lyudmila Publishing House, 92.

4. Kovalenko, V.V., Likhota, A.M., Lishchishin, M.Z. etc. (2017). Collection of local clinical protocols for providing dental care to servicemen with major diseases of the oral cavity in the area of hostilities. K. $45 \mathrm{p}$.

5. Badiuk, M.I., Kovida, D.V., Mikita, O.O., Kozachok, V. Yu., Sereda, I.K., \& Shvets, A.V. (2018). Emergency medical care for servicemen at the pre-hospital stage in the conditions of armed conflicts. K.: SPD Chalchynska NV. 204 p.

6. Klimenko, V.I., Smirnova, I.V. (2014). Risk factors for dental diseases in the working age population. Zaporozhye Med. Journ. 4 (85). 60-62.

7. Kovalenko, V.V., Lishchishin, M.Z. (2017). EuroAtlantic perspectives of domestic dentistry - EuroAtlantic Prospects of World Dentistry. Dentistry news: scientific-practical Journal. 2. 24-27. проведення АТО) з урахуванням стандартів НАТО: методичні рекомендації./ В.В. Коваленко, М.3. Лищишин - К.: УВМА, 2017.- 26 с.

10. Лихота A.M. Сучасні принципи надання медичної допомоги та спеціалізованого лікування поранених в щелепно-лицьову ділянку / А.М. Лихота, В.В. Коваленко // Наука і практика. Міжвідомчий медичний журнал.- 2015.- №1-2 (5-6). - С.44-49.

11. Мельник B.С., Ізай М.Е., Дуганчик Я.I. Аналіз поширеності захворювань зубощелепної системи, які формують попит на стоматологічні послуги //Молодий вчений. -2016. -№12.1 (40) -С.166-169.

12. Стан стоматологічної допомоги військовослужбовцям в зоні проведення антитерористичної операції на Сході України / [А.М. Лихота, В.В. Коваленко, М.З. Лищишин, І.В. Федірко] / / Військ. медицина України. -2015. -Т. 15, №1. - С. 30-35.

13. AJP-3.14. Allied joint doctrine for forse protection/. Edition A, Version 1. With UK national elements/-2015. / - 97 p.

14. STANAG 2466. (Dental Fitness Standards for Military Personnel and a Dental Fitness Classification System. -2014. - 112 p.

15. STANAG 2453 / AMedP-35: The Extent of Dental And Maxillo-facial Treatment at Role 1-3). - 2017. - 148 p.

8. Kovalenko, VV Lishchishin, MZ (2016). Features of the organization of dental care in the area of the antiterrorist operation in eastern Ukraine. Dentistry news. (4). 101.

9. Kovalenko, V.V., Lishchishin, M.Z. (2017). Organization and scope of dental care for servicemen in the combat zone (based on the experience of antiterrorist operation) taking into account NATO standards: methodological recommendations. K.: UVMA. 26.

10. Lihota, A.M. Kovalenko, V.V. (2015). Modern principles of medical care and specialized treatment of wounded in the maxillofacial area. Science and practice. Interdepartmental medical journal. №1-2 (5-6). 44-49.

11. Melnik, V.S., Izay, M.E., Duganchik, Y.I. (2016). Analysis of the prevalence of diseases of the dental system, which form the demand for dental services. $A$ young scientist. №12.1 (40). 166-169.

12. Likhota, A.M., Kovalenko, V.V., Lishchyshyn, M.Z., Fedirko, I.V. (2015). The state of dental care for servicemen in the area of the anti-terrorist operation in eastern Ukraine. Military medicine of Ukraine. 15, (1). 30-35.

13. AJP-3.14. Allied joint doctrine for force protection /. Edition A, Version 1. With UK national elements / -2015. $97 \mathrm{p}$.

14. STANAG 2466. (Dental Fitness Standards for Military Personnel and a Dental Fitness Classification System. 2014. 112 p.

15. STANAG 2453 / AMedP-35: The Extent of Dental And Maxillo-facial Treatment at Role 1-3). 2017. 148 p. 


\title{
УСОВЕРШЕНСТВОВАНИЕ СТОМАТОЛОГИЧЕСКОЙ ПОМОЩИ ВОЕННОСЛУЖАЩИМ ВООРУЖЕННІХ СИЛ УКРАИНЫ В СООТВЕТСТВИИ С ТРЕБОВАНИЯМИ СТАНДАРТОВ НАТО
}

\author{
М.И. Бадюк'1, В.В. Коваленко ${ }^{\text {, В.В. Солярик }}{ }^{1}$, Т.В. Яроші, Т.В. Херсонская ${ }^{2}$
}

1 Украинская военно-медицинская академия, г. Киев, Украина

2 Центральная стоматологическая поликлиника Министерства обороны Украины, г. Киев, Украина

\begin{abstract}
Цель. Научное обоснование улучшения стоматологической помощи военнослужащим ВС Украины путем достижения совместимости медищинских и технологических документов оказания
\end{abstract} стоматологической помощи со стандартами НАТО.

Методы исследования. Методология исследований была основана на системном подходе. Для решения поставленных задач были применены следующие методы исследований: системного анализа (системно-исторический; системно-структурный; системно-элементный; системно-коммуникативный) и методы статистического анализа.

Результаты. $B$ ходе исследования проанализированы показатели работы стоматологической службы ВС Украины при выполнении миротворческих миссий (Либерия, Конго) и в условиях ведения АТО/ООС. Исследованы стандарты НАТО в области организации стоматологической помощи в условиях ведения вооруженного конфликта и определены возможные направления улучшения стоматологической помощи военнослужащим ВС Украины путем адаптации национальных стандартов к стандартам НАТО. Материалы исследования нашли свое отражение в разработанном коллективом стоматологической службы ВС Украины «Сборнике локальных клинических протоколов оказания стоматологической помощи военнослужащим с основными заболеваниями полости рта в зоне ведения боевых действий» (2017 г.), которые на сегодня используются врачами-стоматологами ВС Украины в практической деятельности.

Выводы. Проведенное исследование позволяет утверждать, что существующая организационная структура стоматологической службы ВС Украины позволяет в полном объеме использовать стандарты НАТО и адаптировать алгоритмы и протоколы оказания медицинской помощи при ранениях в Чло в условиях ведения вооруженного конфликта.

Ключевые слова: локальные клинические протоколы, стандарты НАТО, совместимость медикотехнологических документов, станаги, болезни органов полости рта, усовершенствование стоматологической помощи.

\section{IMPROVEMENT OF DENTAL CARE FOR MILITARY SERVICEMEN OF THE ARMED FORCES OF UKRAINE IN ACCORDANCE WITH NATO STANDARDS}

\author{
M. I. Badiuk1, V.V. Kovalenko1, V.V., Solyaryk¹, T. V. Yarosh'1, T. V. Khersonskaja² \\ ${ }^{1}$ Ukrainian Military Medical Academy, Kyiv, Ukraine \\ ${ }^{2}$ Central Dental Clinic of the Ministry of Defense of Ukraine, Kyiv, Ukraine
}

The purpose. The scientific substantiation of improving the provision of dental care to the armed forces of Ukraine by achieving compatibility of medical and technological documents of dental care with NATO standards.

Methods. The research methodology was based on the systemic approach. The following methods of researches were applied for the solution of the tasks: system analysis (systemically-historical; systemically-structural; systemically-element; systemically-communicative) and methods of statistical analysis.

Results. In the study analyzed the performance indicators of the dental service of the armed forces of Ukraine during the peacekeeping missions (Liberia, Congo) and in the CMO. NATO's standards for dental care organization have been researched in the context of armed conflict and the possible directions of improvement of dental care by Ukrainian armed Forces servicemen by adapting national standards to NATO standards. Materials of the research were reflected in the developed collective of Dental Service of the armed Forces of Ukraine «Collection of local clinical protocols of dental care provision to servicemen with major diseases of the oral cavity the area of combat operations "(2017), which are currently being used by dentists of the armed forces of Ukraine in practice.

Conclusions. The study allows to argue that the existing organizational structure of a dental service of the armed forces of Ukraine allows you to fully apply NATO standards and adapt Assistance to servicemen of the armed forces of Ukraine for wounds in the MFA in the context of armed conflict.

Key words: local clinical protocols, NATO standards, compatibility of medical and technological documents, Stanagi, diseases of the oral cavity, improvement of dental care.

Конфлікт інтересів: відсутній.

Conflicts of interest: authors have no conflict of interest to daclare. 


\section{Відомості про авторів:}

Бадюк М.I., A,B,C,D,E,F доктор медичних наук, професор, начальник кафедри організації медичного забезпечення збройних сил Української військово-медичної академії, м. Київ, Україна.

Коваленко В.В., C,D,E, полковник медичної служби, доктор медичних наук, доцент, доцент кафедри щелепно-лицевої хірургії і стоматології Української військово-медичної академії, м. Київ, Україна.

Солярик B.B., C,D,E, кандидат медичних наук, доцент, професор кафедри організації медичного забезпечення збройних сил Української військово-медичної академії, м. Київ, Україна.

Ярош Т.В., С,Е, кандидат технічних наук, доцент, доцент кафедри організації медичного забезпечення збройних сил Української військово-медичної академії, м. Київ, Україна.

Херсонська T.B., ${ }^{\text {CD,E }}$ капітан медичної служби, кандидат медичних наук, ординатор пересувного стоматологічного відділення Центральної стоматологічної поліклініки Міністерства оборони України, м. Київ, Україна.

$A$ - концепція та дизайн дослідження; $B$ - збір даних; $C$ - аналіз та інтерпретація даних;

$D$ - написання статmi; $E$ - редагування статті; F- остаточне затвердження статті.

\section{Сведения об авторах:}

Бадюк М.И., доктор медицинских наук, профессор, начальник кафедры организации медицинского обеспечения вооруженных сил Украинской военно-медицинской академии, г. Киев, Украина

Коваленко В.В., полковник медицинской службы, доктор медицинских наук, доцент, доцент кафедры челюстно-лицевой хирургии и стоматологии Украинской военно-медицинской академии, г.Киев, Украина.

Солярик В.В.,'кандидат медицинских наук, доцент, профессор кафедры организации медицинского обеспечения вооруженных сил Украинской военно-медицинской академии, г. Киев, Украина

Ярош Т.В., кандидат технических наук, доцент, доцент кафедры организации медицинского обеспечения вооруженных сил Украинской военно-медицинской академии, г. Киев, Украина.

Херсонская T.B., капитан медицинской службы, кандидат медицинских наук, ординатор передвижного стоматологического отделения Центральной стоматологической поликлиники Министерства обороны Украины, г. Киев, Украина.

\section{Information about authors:}

Badiuk M.I., A,B,C,D,E,F MD, professor, Head of department of Armed Forces Medical Organization of Ukrainian Military Medical Academy, Address: 45/1 Moscow str., building 33, 01015, Kyiv, Ukraine,

E-mail: badiuk@ukr.net, https://orcid.org/0000-0002-2995-0910.

Kovalenko V.V., C, D, E, Colonel of Medical Service, Doctor of Medical Sciences, Associate Professor, Associate Professor of the Department of Maxillofacial Surgery and Dentistry of the Ukrainian Military Medical Academy, Kyiv, Ukraine.

Solarik V.V., C,D,E, PhD (Med), Associate Professor, professor of department of Armed Forces Medical Organization of Ukrainian Military Medical Academy, E-mail: solyarikw@gmail.com,

Yarosh T.V., C, E, candidate of Technical Sciences, Associate Professor, Associate Professor of the Department of Medical Support of the Armed Forces of the Ukrainian Military Medical Academy, Kyiv, Ukraine.

Khersonskaja T.V., C, D, E Captain of Medical Service, Candidate of Medical Sciences, Resident of the Mobile Dental Department of the Central Dental Clinic of the Ministry of Defense of Ukraine, Kyiv, Ukraine.

$A$ - research concept and design; $B$ - collection and/or assembly of data; $C$-data analysis and interpretation;

$D$-writing the article; $E$ - critical revision of the article; $F$ - final approval of the article.

Адреса для листування: вул. Московська, 45/1, буд. 33, м. Київ 01015 